\title{
Copper Catalyzed Cross-Coupling Reactions of Diaryl Ditellurides with Potassium Aryltrifluoroborate Salts
}

\author{
Diego Alves, ${ }^{*, a}$ Jesus M. Pena, ${ }^{a}$ Adriano S. Vieira, ${ }^{a}$ Giancarlo V. Botteselle, ${ }^{a}$ \\ Rafael C. Guadagnin ${ }^{a}$ and Hélio A. Stefani*a,b \\ ${ }^{a}$ Departamento de Farmácia, Faculdade de Ciências Farmacêuticas, Universidade de São Paulo,
05508-900 São Paulo-SP, Brazil \\ ${ }^{b}$ Departamento de Biofísica, Universidade Federal de São Paulo, 04023-062 São Paulo-SP, Brazil
}

\begin{abstract}
Apresentamos aqui resultados das reações de acoplamento de diteluretos de diarila com sais de ariltrifluoroborato de potássio, usando quantidades catalíticas de $\mathrm{Cu}(\mathrm{OAc})_{2}$ e bipiridina, em uma mistura de $\mathrm{DMSO} / \mathrm{H}_{2} \mathrm{O}$, sob ar atmosférico. Estas reações de acoplamento são gerais e são realizadas com diteluretos de diarila e sais de ariltrifluoroborato de potássio contendo substituintes neutros, retiradores e doadores de elétrons, fornecendo os correspondentes teluretos de diarila não simétricos em rendimentos de bons a excelentes.
\end{abstract}

We present here results of the cross-coupling reaction of diaryl ditellurides with potassium aryltrifluoroborate salts using a catalytic amount of $\mathrm{Cu}(\mathrm{OAc})_{2}$ and bypiridine in $\mathrm{DMSO} / \mathrm{H}_{2} \mathrm{O}$ under air atmosphere. This cross-coupling reaction is general and was performed with diaryl ditellurides and potassium aryltrifluoroborate salts bearing electron-withdrawing, electron-donating and neutral substituents, affording the corresponding unsymmetrical diaryl tellurides in good to excellent yields.

Keywords: tellurium, trifluoroborate salts, copper catalysis

\section{Introduction}

Chalcogenide compounds have become attractive synthetic targets because of their chemo-, regio-, and stereoselective reactions, ${ }^{1-4}$ used in a wide variety of functional groups, thus avoiding protection group chemistry and resulting in useful biological activities. ${ }^{5-7}$ Therefore, many classes of organotellurium compounds have been prepared and studied to date and aryl- or vinylic tellurides are certainly the most useful and promising compounds in view of their usefulness in organic synthesis. ${ }^{8-11}$ A large number of methodologies have been reported to prepare these compounds. ${ }^{49-11}$ However, limited synthetic methods are reported to synthesize unsymmetrical diaryl tellurides. In recent years, a transition-metal-catalyzed reaction of diaryl dichalcogenides with aryl halides or boronic acids has become a versatile tool for synthesis of unsymmetrical diaryl chalcogenides. ${ }^{12-17}$ Recently, Taniguchi ${ }^{12}$ described the preparation of numerous unsymmetrical organotellurides

*e-mail: hstefani@usp.br; dsalves@gmail.com by reaction of organoboronic acids with ditellurides via cleavage of Te-Te bond by a copper catalyst.

In the context of organoboron reagents, significant advances have been made in the use of these compounds as coupling partners in a number of transition-metal mediated reactions. ${ }^{18,19}$ The organoboron compounds most frequently employed are boronic acids and boronate esters, but these compounds have some drawbacks; among them, we can mention the low stability, very high price of some reagents and high sensitivity to air and moisture. To solve these problems, the use of potassium organotrifluoroborates, as the organoboron coupling partner, has some advantages in comparison to boronic acids and boronic esters, such as being more nucleophilic, stable on air, crystalline as solids and easily prepared..$^{20-22}$

The use of potassium aryltrifluoroborate salts in the synthesis of unsymmetrical diaryl chalcogenides was reported by Wang and co-workers. ${ }^{15}$ However, only one example of unsymmetrical diaryl telluride was obtained in moderated yield, under conditions optimized to arylboronic acids. Our continuing interest in the synthesis and reactivity 
of potassium organotrifluoroborate salts ${ }^{22-29}$ prompted us to explore in detail a general procedure to access various unsymmetrical diaryl tellurides by a copper catalyzed crosscoupling reaction of diaryl ditellurides with potassium aryltrifluoroborate salts (Scheme 1).

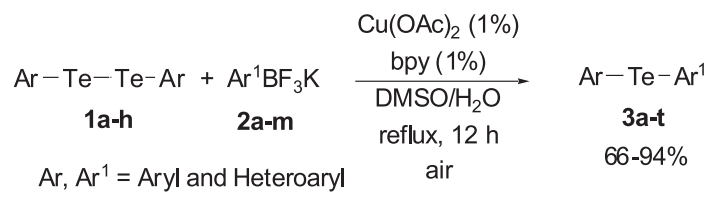

Scheme 1. General scheme for the cross-coupling reaction.

\section{Results and Discussion}

Our initial studies have focused on the development of an optimum set of reaction conditions. In this way, di-( $p$-tolyl) ditelluride 1a and potassium $p$-methoxyphenyltrifluoroborate 2a were used as standard substrates. Thus, a mixture of diaryl ditelluride $\mathbf{1 a}(0.25 \mathrm{mmol})$ and trifluoroborate $\mathbf{2 a}$ (0.5 mmol), utilizing $\mathrm{DMSO} / \mathrm{H}_{2} \mathrm{O}(2: 1)$ as a solvent, was refluxed with different copper catalysts, using bipyridine (bpy) as ligand, in air (Table 1). As shown in Table 1, different catalysts of copper(I) and copper(II) were tested, displaying a moderated to good catalytic activity, and the best result was obtained using $\mathrm{Cu}(\mathrm{OAc})_{2} /$ bpy $(5 \mathrm{~mol} \%)$, giving the desired product 3a in excellent yield (Table 1, entry 6). When the reaction was performed in absence of catalyst and ligand, only traces of the desired product $\mathbf{3 a}$ were obtained (Table 1, entry 10).

Table 1. Study of the catalyst effect on the cross-coupling reaction ${ }^{\mathrm{a}}$

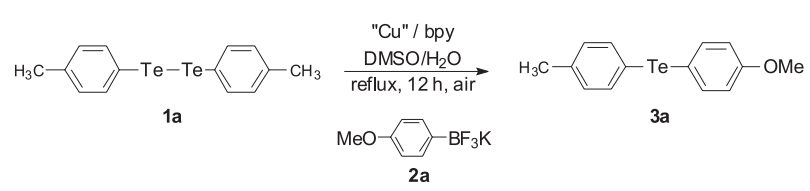

\begin{tabular}{lcc}
\hline Entry & Copper Catalyst $(5 \mathrm{~mol} \%)$ & Yield of $\mathbf{3 a}(\%)^{\mathrm{b}}$ \\
\hline 1 & $\mathrm{CuI}$ & 77 \\
2 & $\mathrm{CuCl}$ & 72 \\
3 & $\mathrm{CuBr}$ & 72 \\
4 & $\mathrm{CuCN}$ & 80 \\
5 & $\mathrm{CuCl}_{2} \cdot 2 \mathrm{H}_{2} \mathrm{O}$ & 75 \\
6 & $\mathrm{Cu}(\mathrm{OAc})_{2}$ & 91 \\
7 & $\mathrm{CuSO}_{4} \cdot 5 \mathrm{H}_{2} \mathrm{O}$ & 78 \\
8 & $\mathrm{CuO}_{2}$ & 69 \\
9 & $\mathrm{Cu}(\mathrm{OTf})_{2}$ & 64 \\
$10^{\mathrm{c}}$ & - & trace
\end{tabular}

a Reactions performed in the presence of $\mathbf{1 a}(0.25 \mathrm{mmol}), \mathbf{2 a}(0.5 \mathrm{mmol})$, $5 \mathrm{~mol} \%$ of catalyst/bpy, in DMSO $(1 \mathrm{~mL})$ and $\mathrm{H}_{2} \mathrm{O}(0.5 \mathrm{~mL}) ;{ }^{\text {b } Y i e l d s ~ a r e ~}$ given for isolated products; 'Without catalyst and ligand.
We observed that the influence of the solvent was important for the coupling success. The reaction mixture of diaryl ditelluride 1a and trifluoroborate 2a using $\mathrm{Cu}(\mathrm{OAc})_{2} /$ bpy $(5 \mathrm{~mol} \%)$ was refluxed with different solvents and the results are summarized in Table 2. Optimal results were achieved using a mixture of $\mathrm{DMSO} / \mathrm{H}_{2} \mathrm{O}(2: 1)$ as solvent (Table 2, entry 1). When using DMSO, toluene and a mixture of toluene/ $\mathrm{H}_{2} \mathrm{O}$ (Table 2, entries 2-4) moderate yields were obtained, while other solvents such as 1,4-dioxane, DMF and $\mathrm{CH}_{3} \mathrm{CN}$ (Table 2, entries 5-7) gave poor yields of the desired product $\mathbf{3 a}$.

When the reaction was carried out with other ligands such as 1,10-phenanthroline, TMEDA and 1,3-diaminopropane or without ligand, a decrease in the yield of product $\mathbf{3 a}$ was observed (Table 2, entries 8-11).

The use of catalyst in an amount of $10 \mathrm{~mol} \%$ yielded $98 \%$ of $3 \mathbf{a}$ (Table 2, entry 12). Fortunately, when the amount of catalyst was reduced from 5 to $1 \mathrm{~mol} \%$, excellent yields of product 3a were obtained (Table 2, entries 13 and 14).

Table 2. Reaction conditions optimization ${ }^{\mathrm{a}}$

\begin{tabular}{|c|c|c|c|}
\hline Entry & Solvent & Ligand & Yield of $\mathbf{3 a}(\%)^{\mathrm{b}}$ \\
\hline 1 & $\mathrm{DMSO} / \mathrm{H}_{2} \mathrm{O}$ & bpy & 91 \\
\hline 2 & DMSO & bpy & 56 \\
\hline 3 & Toluene & bpy & 72 \\
\hline 4 & Toluene $/ \mathrm{H}_{2} \mathrm{O}$ & bpy & 56 \\
\hline 5 & 1,4-dioxane & bpy & 42 \\
\hline 6 & DMF & bpy & 31 \\
\hline 7 & $\mathrm{CH}_{3} \mathrm{CN}$ & bpy & 29 \\
\hline 8 & $\mathrm{DMSO} / \mathrm{H}_{2} \mathrm{O}$ & 1,10-phenanthroline & 75 \\
\hline 9 & $\mathrm{DMSO} / \mathrm{H}_{2} \mathrm{O}$ & TMEDA & 80 \\
\hline 10 & $\mathrm{DMSO} / \mathrm{H}_{2} \mathrm{O}$ & 1,3-diaminopropane & 69 \\
\hline 11 & $\mathrm{DMSO} / \mathrm{H}_{2} \mathrm{O}$ & - & 75 \\
\hline $12^{\mathrm{c}}$ & $\mathrm{DMSO} / \mathrm{H}_{2} \mathrm{O}$ & bpy & 98 \\
\hline $13^{\mathrm{d}}$ & $\mathrm{DMSO} / \mathrm{H}_{2} \mathrm{O}$ & bpy & 90 \\
\hline $14^{\mathrm{e}}$ & $\mathrm{DMSO} / \mathrm{H}_{2} \mathrm{O}$ & bpy & 90 \\
\hline
\end{tabular}

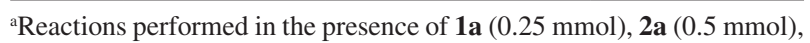
$5 \mathrm{~mol} \%$ of $\mathrm{Cu}(\mathrm{OAc})_{2} /$ Ligand and solvent $(1 \mathrm{~mL})$; 'Yields are given for isolated products; ${ }^{\mathrm{c}} 10 \mathrm{~mol} \%$ of $\mathrm{Cu}(\mathrm{OAc})_{2} / \mathrm{bpy} ;{ }^{\mathrm{d}} 3 \mathrm{~mol} \%$ of $\mathrm{Cu}(\mathrm{OAc})_{2} /$ bpy; ${ }^{\mathrm{e}} 1 \mathrm{~mol} \%$ of $\mathrm{Cu}(\mathrm{OAc})_{2} / \mathrm{bpy}$.

Careful analysis of the optimized reactions revealed that the optimum conditions for this coupling reaction were found to be the use of $\mathrm{Cu}(\mathrm{OAc})_{2} / \mathrm{bpy}(1 \mathrm{~mol} \%)$ as the catalytic system, diaryl ditelluride $\mathbf{1 a}(0.25 \mathrm{mmol})$, potassium aryltrifluoroborate salt $\mathbf{2 a}(0.5 \mathrm{mmol})$, and a 
mixture of DMSO/ $\mathrm{H}_{2} \mathrm{O}(2: 1, \mathrm{v} / \mathrm{v})$ as a solvent. The reaction mixture was refluxed for $12 \mathrm{~h}$ under air atmosphere, affording the desired diaryl telluride $\mathbf{3 a}$ with $90 \%$ yield. ${ }^{30}$

In order to demonstrate the efficiency of this protocol, we explored the generality of our method reacting others potassium aryltrifluoroborate salts $\mathbf{2 a - m}$ with diaryl ditelluride 1a and these results are summarized in Table 3. Table 3 shows that the reaction worked well for a range of potassium aryltrifluoroborate salts. These results revealed that the reaction is sensitive to the electronic effect of the aromatic ring in the potassium aryltrifluoroborate salt. For example, trifluoroborate salts 2a-e, bearing electrondonating and electron-neutral groups at the aromatic ring, gave better yields than the trifluoroborates bearing electronwithdrawing groups (Table 3, entries 1-5 versus 6-10). When we used potassium heteroaryltrifluoroborate salts $2 \mathbf{k}-\mathbf{m}$, the desired products were obtained in good yields (Table 3, entries 11-13).

In an attempt to broaden the scope of our methodology, the possibility of performing the reaction with other diaryl ditellurides was also investigated (Table 4). Potassium trifluoroborate 2a was cross-coupled efficiently with a variety of ditellurides $\mathbf{1 b}$-h. A decrease in the reaction yield was observed using hindered or heteroaryl ditellurides $\mathbf{1 f}-\mathbf{h}$ (Table 4, entries 5-7).

We believe that the mechanism of this cross-coupling reaction is in accordance with the proposed by Tanigushi, ${ }^{12}$ using organoboronic acids analogues. It seems that the reaction requires DMSO/ $\mathrm{H}_{2} \mathrm{O}$ and oxygen of air to oxidize the copper intermediates and promote the reaction.

The compounds obtained by this protocol appear highly promising as intermediates in the preparation of more complexes molecules. In the last decade, Uemura ${ }^{31}$ described the use of symmetrical diaryl tellurides utilizing Heck palladium catalyzed cross-coupling and the two symmetrical aryl groups of telluride were transferred to various alkenes. For instance, the resulting unsymmetrical diaryl tellurides should be particularly useful intermediates in this type of reaction. In this way, compound $\mathbf{3 a}$ was coupled with ethyl acrylate, using the conditions described by Uemura ${ }^{31}$ (Scheme 2).

In this reaction, unsymmetrical diaryl telluride $\mathbf{3 a}$ transfers the two different aryl groups to ethyl acrylate, giving two products of cross-coupling $\mathbf{4 a}$ and $\mathbf{4 b}$ in excellent yields. ${ }^{32}$

\section{Conclusions}

We have explored in details the cross-coupling reaction of diaryl ditellurides with potassium aryltrifluoroborate salts using a catalytic amount of $\mathrm{Cu}(\mathrm{OAc})_{2} / \mathrm{bpy}$ in a mixture
Table 3. Coupling products using diaryl ditelluride $\mathbf{1 a}$ and potassium aryl trifluoroborate salts $\mathbf{2 a - \mathbf { m }}$

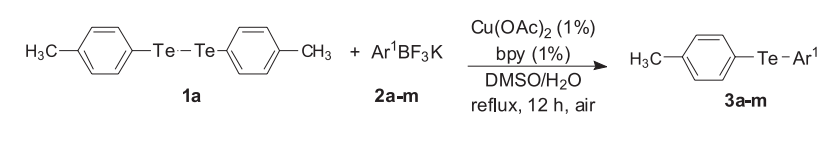

\begin{tabular}{|c|c|c|}
\hline Entry & $\mathrm{Ar}^{1} \mathrm{BF}_{3} \mathrm{~K}$ & Product Yield (\%) ${ }^{a}$ \\
\hline
\end{tabular}

2
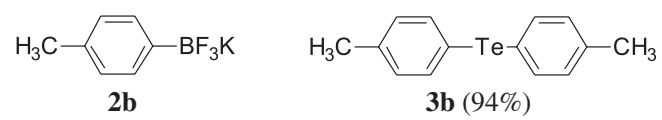

3

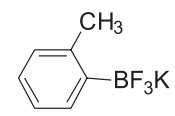

2c

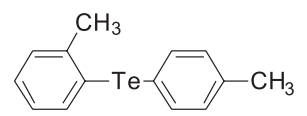

3c $(89 \%)$

4

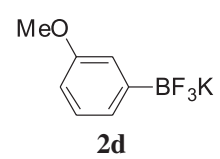

$\mathrm{MeO}$

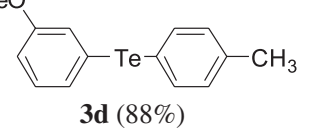

5

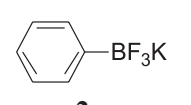

$2 \mathrm{e}$

6
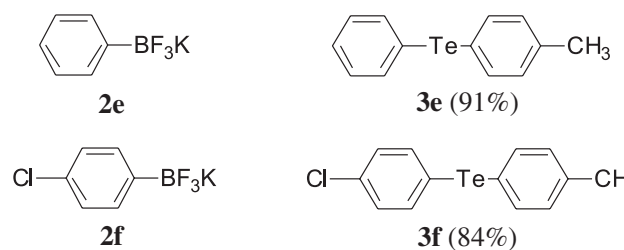

3e $(91 \%)$
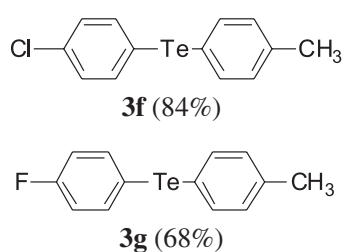

$2 \mathrm{~g}$

8
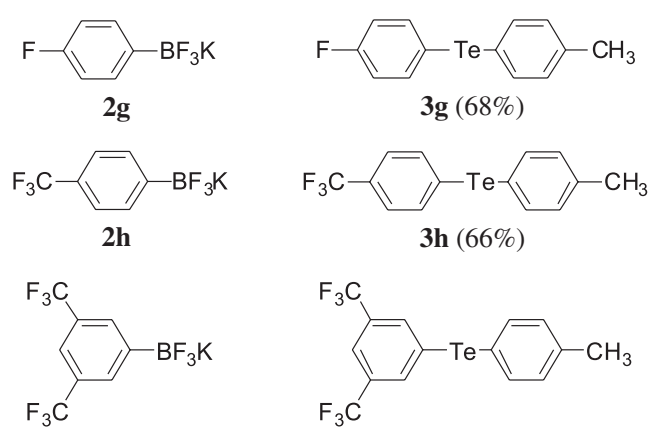

$2 \mathbf{i}$

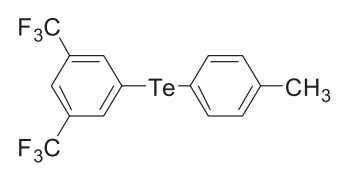

$3 \mathbf{i}(68 \%)$

10

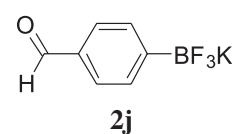

11
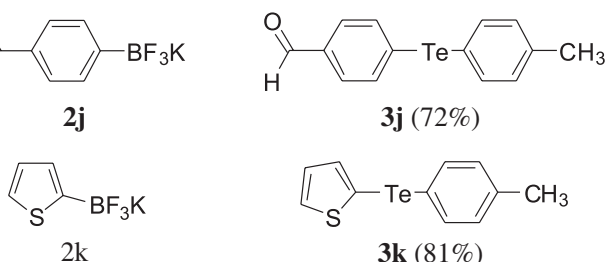

3j $(72 \%)$

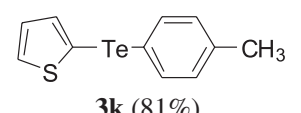

3k $(81 \%)$

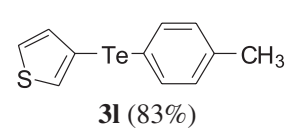

21

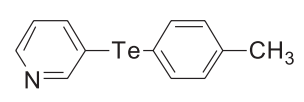

3m $(78 \%)$

${ }^{\text {a }}$ Yields are given for isolated products. 
Table 4. Coupling products using diaryl ditellurides $\mathbf{1 b}$-h and potassium aryltrifluoroborate salt $\mathbf{2 a}$

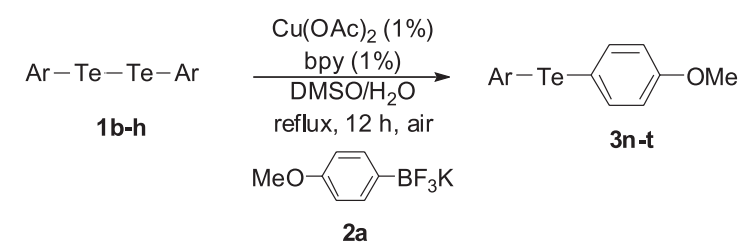

Entry

${ }^{a}$ Yields are given for isolated products.

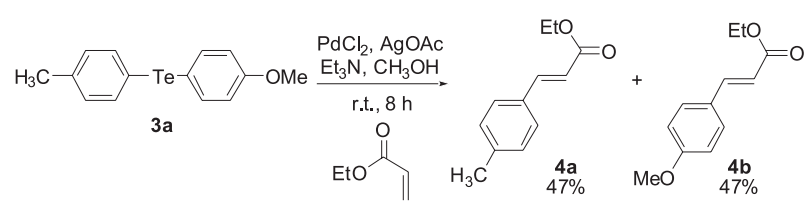

Scheme 2. Application of compound 3a in a Heck cross-coupling reaction.

of DMSO/ $\mathrm{H}_{2} \mathrm{O}$ under air atmosphere and established a new route to obtain unsymmetrical diaryl tellurides in good to excellent yields. Subsequent Heck cross-coupling reactions of compound 3a with alkenes proceed smoothly in excellent yields and transfer the two different aryl groups from diaryl tellurides. Studies of the Heck reactions are under investigation and will be reported in due course.

\section{Supplementary Information}

Supplementary information, with extra experimental and characterization data, is available free of charge at http://jbcs.sbq.org.br, as PDF file.

\section{Acknowledgments}

The authors would like to thank Conselho Nacional de Desenvolvimento Científico e Tecnológico (CNPq) and Fundação de Amparo à Pesquisa do Estado de São Paulo (FAPESP) (Grants 07/56659-0 and 07/59404-2) for financial support.

\section{References}

1. Wirth, T., ed. In Topics in Current Chemistry: Organoselenium Chemistry, Springer-Verlag: Heidelberg, 2000, p. 208.

2. Krief, A. In Comprehensive Organometallic Chemistry II; Abel, E. V.; Stone, F. G. A.; Wilkinson, G.; eds.; Pergamon Press: New York, 1995, vol. 11, ch. 13.

3. Paulmier, C. In Selenium Reagents and Intermediates in Organic Synthesis; Baldwin, J. E.; ed.; Pergamon Press: Oxford, 1986, Organic Chemistry Series 4.

4. Petragnani, N.; Stefani, H. A.; Tellurium in Organic Synthesis, $2^{\text {nd }}$ ed., Academic Press: London, 2007.

5. Nogueira, C. W.; Zeni, G.; Rocha, J. B. T.; Chem. Rev. 2004, 104, 6255 .

6. Mugesh, G.; du Mont, W.-W.; Sies, H.; Chem. Rev. 2001, 101, 2125.

7. Parnham, M. J.; Graf, E.; Prog. Drug. Res. 1991, 36, 9.

8. Zeni, G.; Braga, A. L.; Stefani, H. A.; Acc. Chem. Res. 2003, 36,731 .

9. Zeni, G.; Ludtke, D. S.; Panatieri, R. B.; Braga, A. L.; Chem. Rev. 2006, 106, 1032.

10. Petragnani, N.; Stefani, H. A.; Tetrahedron 2005, 61, 1613.

11. Comasseto, J. V.; Ling, L. W.; Petragnani, N.; Stefani, H. A.; Synthesis 1997, 373.

12. Taniguchi, N.; J. Org. Chem. 2007, 72, 1241.

13. Taniguchi, N.; Synlett 2006, 1351.

14. Taniguchi, N.; Onami, T.; J. Org. Chem. 2004, 69, 915.

15. Wang, L.; Wang, M.; Huang, F.; Synlett 2005, 2007.

16. Fukuzawa, S.; Tanihara, D.; Kikuchi, S.; Synlett 2006, 2145.

17. Kumar, S.; Engman, L.; J. Org. Chem. 2006, 71, 5400.

18. Suzuki, A. In Metal-Catalyzed Cross-Coupling Reactions; Diederich, F.; Stang, P. J., eds.; Wiley-VHC: Weinheim, 1998.

19. Lloyd-Williams, P.; Giralt, E.; Chem. Soc. Rev. 2001, 30, 145.

20. Molander, G. A.; Ellis, N.; Acc. Chem. Res. 2007, 40, 275.

21. Darses, S.; Genêt, J.-P.; Chem. Rev. 2008, 108, 288.

22. Stefani, H. A.; Cella, R.; Vieira, A. S.; Tetrahedron 2007, 63, 3623. 
23. Cella, R.; Cunha, R. L. O. R.; Reis, A. E. S.; Pimenta, D. C.; Klitzke, C. F.; Stefani, H. A.; J. Org. Chem. 2006, 71, 224.

24. Cella, R.; Stefani, H. A.; Tetrahedron 2006, 62, 5656.

25. Stefani, H. A.; Cella, R.; Dörr, F. A.; Pereira, C. M. P.; Zeni G.; Gomes, M. Jr.; Tetrahedron Lett. 2005, 46, 563.

26. Cella, R.; Orfão, A. T. G.; Stefani, H. A.; Tetrahedron Lett. 2006, 47, 5075.

27. Cella, R.; Venturoso, R. C.; Stefani, H. A.; Tetrahedron Lett. 2008, 49, 16.

28. Vieira, A. S.; Ferreira, F. P.; Fiorante, P. F.; Guadagnin, R. C.; Stefani, H. A.; Tetrahedron 2008, 64, 3306.

29. Vieira, A. S.; Fiorante, P. F.; Zukerman-Schpector, J.; Alves, D.; Botteselle, G. V.; Stefani, H. A.; Tetrahedron 2008, 64, 7234.

30. General procedure for the cross-coupling reaction of diaryl ditellurides with potassium aryltrifluoroborates: To a roundbottomed flask containing diaryl ditelluride $(0.25 \mathrm{mmol})$, potassium aryltrifluoroborate salt $(0.5 \mathrm{mmol}), \mathrm{Cu}(\mathrm{OAc})_{2}$ (1 mol\%) and bpy (1 mol\%), DMSO $(1 \mathrm{~mL})$ and $\mathrm{H}_{2} \mathrm{O}(0.5 \mathrm{~mL})$ were added. The reaction mixture was allowed to stir at reflux for $12 \mathrm{~h}$. After this time, the solution was cooled to room temperature, diluted with dichloromethane $(20 \mathrm{~mL})$ and washed with saturated aqueous $\mathrm{NH}_{4} \mathrm{Cl}(3 \times 20 \mathrm{~mL})$. The organic phase was separated, dried over $\mathrm{MgSO}_{4}$ and concentrated under vacuum. The residue was purified by flash chromatography on silica gel using ethyl acetate/hexane as the eluent. Selected spectral and analytical data for $p$-Methoxyphenyl-p-tolyltelluride (3a): Yield: $0.146 \mathrm{~g}$ (90\%). ${ }^{1} \mathrm{H} \mathrm{NMR}\left(\mathrm{CDCl}_{3}, 300\right.$
MHz): $\delta 7.69$ (d, J $8.5 \mathrm{~Hz}, 2 \mathrm{H}), 7.53(\mathrm{~d}, J 7.8 \mathrm{~Hz}, 2 \mathrm{H}), 7.02$ (d, J 7.8 Hz, 2H), 6.79 (d, J 8.5 Hz, 2H), 3.80 (s, 3H), 2.32 (s, $3 \mathrm{H}) .{ }^{13} \mathrm{C} \mathrm{NMR}\left(\mathrm{CDCl}_{3}, 75 \mathrm{MHz}\right): \delta 159.64,140.36,137.25$, 137.02, 130.10, 115.26, 111.21, 103.48, 54.96, 20.96. MS (relative intensity) $\mathrm{m} / \mathrm{z}: 328$ (28), 198 (100), 183 (74), 155 (25), 91 (23), 65 (17). HRMS calc. for $\mathrm{C}_{14} \mathrm{H}_{14}$ OTe: 328.0107 . Found: 328.0111 .

31. Nishibayashi, Y.; Cho, C. S.; Uemura, S.; J. Organomet. Chem. 1996, 507, 197.

32. General procedure for the Heck cross-coupling reaction of unsymmetrical diaryl telluride (3a) with ethyl acrylate: Into a two-necked $25 \mathrm{~mL}$ round-bottomed flask containing $\mathrm{PdCl}_{2}$ (0.05 mmol), AgOAc (2.00 mmol) and unsymmetrical diaryl telluride 3a $(0.50 \mathrm{mmol})$, dry methanol $(10 \mathrm{~mL}), \mathrm{Et}_{3} \mathrm{~N}(2.00$ $\mathrm{mmol})$ and ethyl acrylate $(1.00 \mathrm{mmol})$ were added. After stirring for $8 \mathrm{~h}$ at $25^{\circ} \mathrm{C}$, the heterogeneous reaction mixture was filtered. The filtrate was poured into brine $(60 \mathrm{~mL})$ and extracted with ethyl acetate $(3 \times 20 \mathrm{~mL})$. The organic phase was separated, dried over $\mathrm{MgSO}_{4}$ and concentrated under vacuum. The residue was purified by flash chromatography on silica gel using ethyl acetate/hexane as the eluent.

Received: July 23, 2008

Web Release Date: March 20, 2009

FAPESP helped in meeting the publication costs of this article. 


\title{
Copper Catalyzed Cross-Coupling Reactions of Diaryl Ditellurides with Potassium Aryltrifluoroborate Salts
}

\author{
Diego Alves, ${ }^{*, a}$ Jesus M. Pena, ${ }^{a}$ Adriano S. Vieira, ${ }^{a}$ Giancarlo V. Botteselle, ${ }^{a}$ \\ Rafael C. Guadagnin ${ }^{a}$ and Hélio A. Stefani*a,b \\ ${ }^{a}$ Departamento de Farmácia, Faculdade de Ciências Farmacêuticas, Universidade de São Paulo, \\ 05508-900 São Paulo-SP, Brazil \\ ${ }^{b}$ Departamento de Biofísica, Universidade Federal de São Paulo, 04023-062 São Paulo-SP, Brazil
}

\section{General informations}

All air-sensitive and/or water-sensitive reactions were carried out under nitrogen atmosphere with dry solvents and anhydrous conditions. Standard syringe techniques were applied for transfer of dry solvents and some airsensitive reagents; needles were introduced into reaction vessels through a rubber septum. The reactions were monitored by TLC carried out on Merck silica gel $\left(60 \mathrm{~F}_{254}\right)$ by using UV light as visualizing agent and 5\% vanillin in $10 \% \mathrm{H}_{2} \mathrm{SO}_{4}$ and heat as developing agents. Merck silica gel (particle size 0.040-0.063 mm) was used for flash chromatography. THF was distilled from sodiumbenzophenone before use. NMR spectra were recorded with Bruker DPX 300 (300 MHz) instrument using $\mathrm{CDCl}_{3}$ as solvent and calibrated using tetramethylsilane as internal standard. Chemical shifts are reported in $\delta(\mathrm{ppm})$ relative to $\left(\mathrm{CH}_{3}\right)_{4} \mathrm{Si}$ for ${ }^{1} \mathrm{H}$ and $\mathrm{CDCl}_{3}$ for ${ }^{13} \mathrm{C} \mathrm{NMR}$. Coupling constants $(J)$ are reported in Hertz. Mass spectra (MS) were measured on a Shimadzu GCMS-QP5050A mass spectrometer. The
HRMS spectra were measured on a Bruker Daltonics Micro TOF (direct inlet probe).

\section{Experimental}

General procedure for the cross-coupling reaction of diaryl ditellurides with potassium aryltrifluoroborates

To a round-bottomed flask containing diaryl ditelluride $(0.25 \mathrm{mmol})$, potassium aryltrifluoroborate salt $(0.5 \mathrm{mmol})$, $\mathrm{Cu}(\mathrm{OAc})_{2}(1 \mathrm{~mol} \%)$ and bpy (1 mol\%), DMSO (1 mL) and $\mathrm{H}_{2} \mathrm{O}(0.5 \mathrm{~mL})$ were added. The reaction mixture was allowed to stir at reflux for $12 \mathrm{~h}$. After this time, the solution was cooled to room temperature, diluted with dichloromethane $(20 \mathrm{~mL})$ and washed with saturated aqueous $\mathrm{NH}_{4} \mathrm{Cl}$ $(3 \times 20 \mathrm{~mL})$. The organic phase was separated, dried over $\mathrm{MgSO}_{4}$ and concentrated under vacuum. The residue was purified by flash chromatography on silica gel using ethyl acetate/hexane as the eluent.
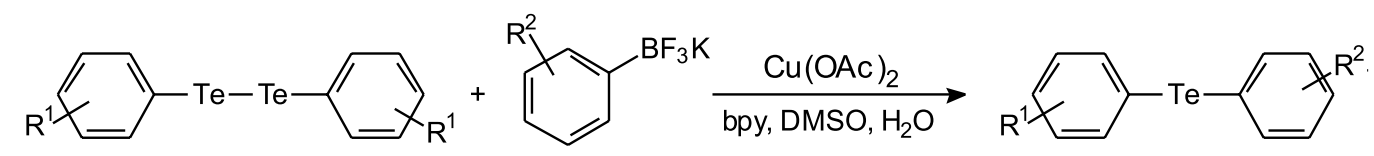

3 a-t

\footnotetext{
*e-mail: hstefani@usp.br; dsalves@gmail.com
} 
General procedure for the Heck cross-coupling reaction of unsymmetrical diaryl telluride (3a) with ethyl acrylate

Into a two-necked $25 \mathrm{~mL}$ round-bottomed flask containing $\mathrm{PdCl}_{2}(0.05 \mathrm{mmol}), \mathrm{AgOAc}(2.00 \mathrm{mmol})$ and unsymmetrical diaryl telluride $\mathbf{3 a}(0.50 \mathrm{mmol})$, dry methanol $(10 \mathrm{~mL}), \mathrm{Et}_{3} \mathrm{~N}(2.00 \mathrm{mmol})$ and ethyl acrylate
$(1.00 \mathrm{mmol})$ were added. After the heterogeneous reaction mixture had been stirred at $25^{\circ} \mathrm{C}$ for $8 \mathrm{~h}$, the solid part was filtered. The filtrate was poured into brine $(60 \mathrm{~mL})$ and extracted with ethyl acetate $(3 \times 20 \mathrm{~mL})$. The organic phase was separated, dried over $\mathrm{MgSO}_{4}$ and concentrated under vacuum. The residue was purified by flash chromatography on silica gel using ethyl acetate/hexane as the eluent.

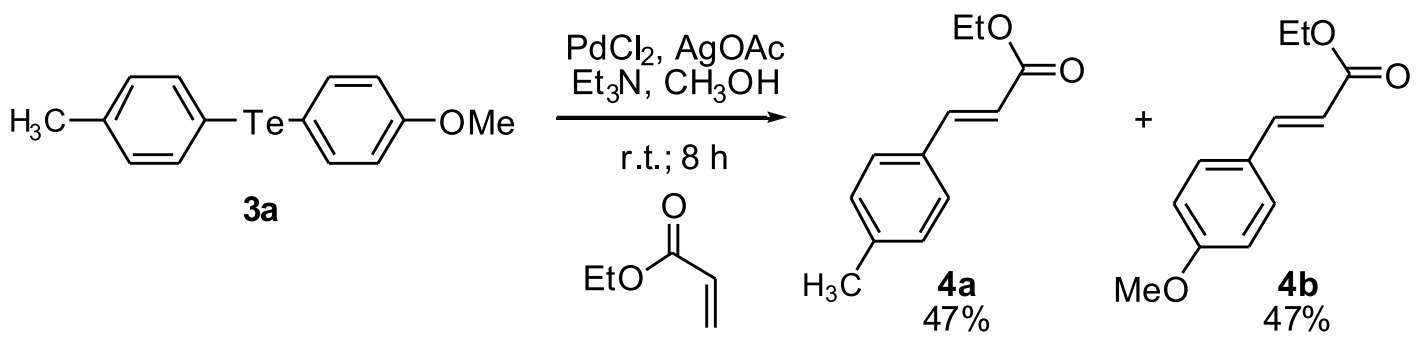

\section{Description of the products}

4-Methoxyphenyl-p-tolyl-telluride (3a)

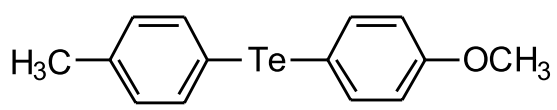

3a

Yield: $90 \% .{ }^{1} \mathrm{H} \mathrm{NMR}\left(\mathrm{CDCl}_{3}, 300 \mathrm{MHz}\right): \delta 7.69(\mathrm{~d}$, $J 8.5 \mathrm{~Hz}, 2 \mathrm{H}), 7.53(\mathrm{~d}, J 7.8 \mathrm{~Hz}, 2 \mathrm{H}), 7.02(\mathrm{~d}, J 7.8 \mathrm{~Hz}$, $2 \mathrm{H}), 6.79(\mathrm{~d}, J 8.5 \mathrm{~Hz}, 2 \mathrm{H}), 3.80(\mathrm{~s}, 3 \mathrm{H}), 2.32(\mathrm{~s}, 3 \mathrm{H})$. ${ }^{13} \mathrm{C}$ NMR $\left(\mathrm{CDCl}_{3}, 75 \mathrm{MHz}\right): \delta 159.64,140.36,137.25$, 137.02, 130.10, 115.26, 111.21, 103.48, 54.96, 20.96. MS (relative intensity) $m / z: 328$ (28), 198 (100), 183 (74), 155 (25), 91 (23), 65 (17). HRMS calculated for $\mathrm{C}_{14} \mathrm{H}_{14} \mathrm{OTe}$ : 328.0107. Found: 328.0111.

Bis-(p-Tolyl)-telluride (3b)

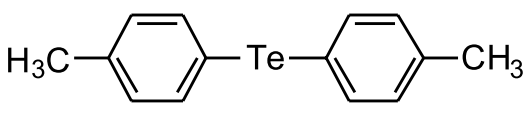

$3 b$

Yield: 94\%. ${ }^{1} \mathrm{H}$ NMR $\left(\mathrm{CDCl}_{3}, 300 \mathrm{MHz}\right): \delta 7.57$ (d, $J$ $7.7 \mathrm{~Hz}, 4 \mathrm{H}), 7.01$ (d, $J 7.7 \mathrm{~Hz}, 4 \mathrm{H}), 2.33(\mathrm{~s}, 6 \mathrm{H}) .{ }^{13} \mathrm{C} \mathrm{NMR}$ $\left(\mathrm{CDCl}_{3}, 75 \mathrm{MHz}\right): \delta 139.2$ (2C), 136.9 (4C), $131.4(4 \mathrm{C})$, 110.7 (2C), 22.0. MS (relative intensity) $\mathrm{m} / \mathrm{z}: 312$ (34), 182 (100), 167 (72), 91 (59), 65 (36). HRMS calculated for $\mathrm{C}_{14} \mathrm{H}_{14}$ Te: 312.0157 . Found: 312.0169 .
p-Tolyl-o-tolyl-telluride (3c)

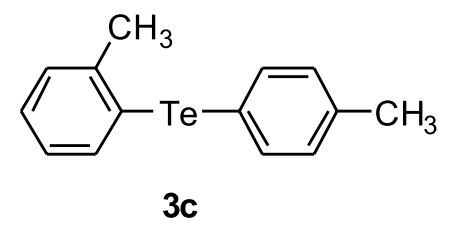

Yield: $89 \% .{ }^{1} \mathrm{H} N M R\left(\mathrm{CDCl}_{3}, 300 \mathrm{MHz}\right): \delta 7.64(\mathrm{~d}, J$ $7.5 \mathrm{~Hz}, 2 \mathrm{H}), 7.49$ (d, J 7.5 Hz, 1H), 7.13-7.22 (m, 2H), 7.07 (d, J 7.5 Hz, 2H), $6.93(\mathrm{t}, J 7.5 \mathrm{~Hz}, 1 \mathrm{H}), 2.40(\mathrm{~s}, 3 \mathrm{H}), 2.36$ (s, 3H). ${ }^{13} \mathrm{C}$ NMR $\left(\mathrm{CDCl}_{3}, 75 \mathrm{MHz}\right): \delta 141.4,139.5(2 \mathrm{C})$, 138.1, 136.4, 130.6 (2C), 129.3, 127.7, 126.7, 119.7, 109.6, 25.8, 21.3. MS (relative intensity) $\mathrm{m} / \mathrm{z}: 312$ (54), 220 (10), 182 (38), 167 (100), 91 (81), 65 (40). HRMS calculated for $\mathrm{C}_{14} \mathrm{H}_{14}$ Te: 312.0157 . Found: 312.0167 .

\section{3-Methoxyphenyl-p-tolyl-telluride (3d)}

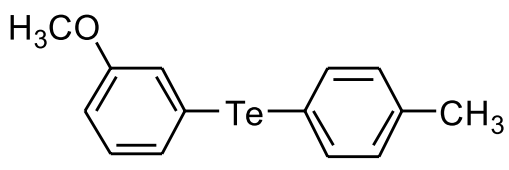

3d

Yield: $88 \%$. ${ }^{1} \mathrm{H}$ NMR $\left(\mathrm{CDCl}_{3}, 300 \mathrm{MHz}\right): \delta 7.63(\mathrm{~d}, J$ $7.8 \mathrm{~Hz}, 2 \mathrm{H}), 7.18-7.22(\mathrm{~m}, 1 \mathrm{H}), 7.15-7.17(\mathrm{~m}, 1 \mathrm{H}), 7.07$ (s, 1H), $7.03(\mathrm{~d}, J 7.8 \mathrm{~Hz}, 2 \mathrm{H}), 6.76(\mathrm{~d}, J 7.5 \mathrm{~Hz}, 1 \mathrm{H}), 3.72$ (s, 3H), 2.32 (s, 3H). ${ }^{13} \mathrm{C} \mathrm{NMR}\left(\mathrm{CDCl}_{3}, 75 \mathrm{MHz}\right): \delta 159.6$, 138.7 (2C), 137.9, 130.2 (2C), 129.9, 129.2, 122.2, 115.8, 113.1, 109.9, 55.0, 21.0. MS (relative intensity) $\mathrm{m} / \mathrm{z}: 328$ (28), 198 (100), 167 (23), 155 (17), 91 (36), 77 (17), 65 (21). HRMS calculated for $\mathrm{C}_{14} \mathrm{H}_{14}$ OTe: 328.0107. Found: 328.0118 . 
Phenyl-p-tolyl-telluride (3e)

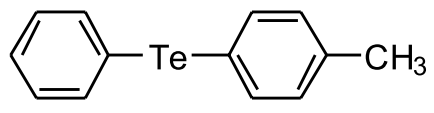

$3 e$

Yellow oil: Yield: 91\%. ${ }^{1} \mathrm{H} \mathrm{NMR}\left(\mathrm{CDCl}_{3}, 300 \mathrm{MHz}\right)$ : $\delta 7.61(\mathrm{~d}, J 7.8 \mathrm{~Hz}, 2 \mathrm{H}), 7.19-7.24(\mathrm{~m}, 3 \mathrm{H}), 7.15(\mathrm{~d}, J 7.8$ $\mathrm{Hz}, 2 \mathrm{H}), 7.00(\mathrm{t}, J 7.8 \mathrm{~Hz}, 2 \mathrm{H}), 2.30$ (s, 3H). ${ }^{13} \mathrm{C} \mathrm{NMR}$ $\left(\mathrm{CDCl}_{3}, 75 \mathrm{MHz}\right): \delta 138.6$ (2C), 137.9, 137.1 (2C), 130.3 (2C), 129.2 (2C), 127.3, 115.1, 110.1, 21.0. MS (relative intensity) $m / z$ : 298 (31), 168 (100), 167 (83), 153 (20), 91 (39), 77 (24), 65 (25). HRMS calculated for $\mathrm{C}_{13} \mathrm{H}_{12} \mathrm{Te}$ : 298.0001. Found: 298.0018.

4-Chlorophenyl-p-tolyl-telluride (3f)

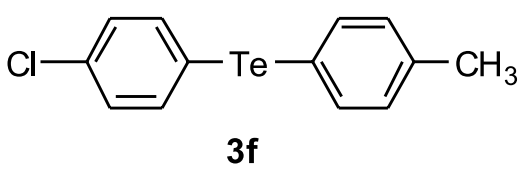

Yield: $84 \%$. ${ }^{1} \mathrm{H}$ NMR $\left(\mathrm{CDCl}_{3}, 300 \mathrm{MHz}\right): \delta 7.60(\mathrm{~d}, J$ $7.2 \mathrm{~Hz}, 2 \mathrm{H}), 7.49$ (d, J 7.2 Hz, 2H), $7.11(\mathrm{~d}, J 7.2 \mathrm{~Hz}, 2 \mathrm{H})$, 7.02 (d, J 7.2 Hz, 2H), 2.31 (s, 3H). ${ }^{13} \mathrm{C} \mathrm{NMR}\left(\mathrm{CDCl}_{3}, 75\right.$ $\mathrm{MHz}): \delta 139.4,138.9$ (2C), 138.5 (2C), 134.0, 130.6 (2C), 129.6 (2C), 113.0, 110.0, 21.3. MS (relative intensity) $\mathrm{m} / \mathrm{z}$ : 332 (31), 202 (100), 167 (62), 91 (48), 65 (33). HRMS calculated for $\mathrm{C}_{13} \mathrm{H}_{11}$ ClTe: 331.9611 . Found: 331.9627.

4-Fluorophenyl-p-tolyl-telluride (3g)

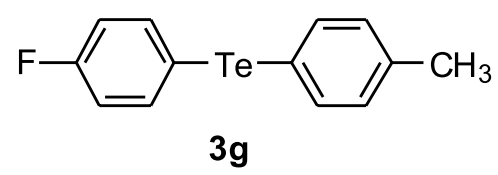

Yield: $68 \% .{ }^{1} \mathrm{H} \mathrm{NMR}\left(\mathrm{CDCl}_{3}, 300 \mathrm{MHz}\right): \delta 7.65(\mathrm{~d}, J$ $7.8 \mathrm{~Hz}, 2 \mathrm{H}), 7.56(\mathrm{~d}, J 7.5 \mathrm{~Hz}, 2 \mathrm{H}), 7.02(\mathrm{~d}, J 7.8 \mathrm{~Hz}, 2 \mathrm{H})$, $6.88(\mathrm{~d}, J 7.5 \mathrm{~Hz}, 2 \mathrm{H}), 2.31(\mathrm{~s}, 3 \mathrm{H}) .{ }^{13} \mathrm{C} \mathrm{NMR}\left(\mathrm{CDCl}_{3}\right.$, $75 \mathrm{MHz}$ ): $\delta$ 164.5, 161.2, 140.1 (2C), 138.0 (2C), 130.5 (2C), 117.2 (2C), 110.5, 108.6, 21.3. MS (relative intensity) $\mathrm{m} / z: 316$ (35), 186 (100), 165 (13), 91 (47), 65 (32). HRMS calculated for $\mathrm{C}_{13} \mathrm{H}_{11} \mathrm{FTe:}$ 315.9907. Found: 315.9918.
4-(Trifluoromethyl)-phenyl-p-tolyl-telluride (3h)<smiles>Cc1ccc([Te]c2ccc(C(F)(F)F)cc2)cc1</smiles>

$3 h$

Yield: 66\%. ${ }^{1} \mathrm{HNMR}\left(\mathrm{CDCl}_{3}, 300 \mathrm{MHz}\right): \delta 7.72(\mathrm{~d}, J$ $7.8 \mathrm{~Hz}, 2 \mathrm{H}), 7.60$ (d, J 7.8 Hz, 2H), 7.37 (d, J $7.5 \mathrm{~Hz}, 2 \mathrm{H})$, $7.11(\mathrm{~d}, J 7.5 \mathrm{~Hz}, 2 \mathrm{H}), 2.37$ (s, 3H). ${ }^{13} \mathrm{C} \mathrm{NMR}\left(\mathrm{CDCl}_{3}\right.$, $75 \mathrm{MHz}): \delta 140.0$ (2C), 139.1, 138.0, 135.8 (2C), 130.8 (2C), 126.2, 125.8 (2C), 121.6, 109.1, 21.3. MS (relative intensity) $m / z: 366$ (43), 236 (97), 221 (17), 167 (67), 126 (16), 91 (100), 65 (61). HRMS calculated for $\mathrm{C}_{14} \mathrm{H}_{11} \mathrm{~F}_{3} \mathrm{Te}$ : 365.9875. Found: 365.9890 .<smiles>Cc1ccc([Te]c2cc(C(F)(F)F)cc(C(F)(F)F)c2)cc1</smiles>

Yield: $68 \% .{ }^{1} \mathrm{H}$ NMR $\left(\mathrm{CDCl}_{3}, 300 \mathrm{MHz}\right): \delta 7.90(\mathrm{~s}$, 2H), $7.72(\mathrm{~d}, J 7.8 \mathrm{~Hz}, 2 \mathrm{H}), 7.67(\mathrm{~s}, 1 \mathrm{H}), 7.12(\mathrm{~d}, J 7.8 \mathrm{~Hz}$, $2 \mathrm{H}), 2.38$ (s, $3 \mathrm{H}) .{ }^{13} \mathrm{C} \mathrm{NMR}\left(\mathrm{CDCl}_{3}, 75 \mathrm{MHz}\right): \delta 140.0(2 \mathrm{C})$, 139.7, 135.4 (2C), 132.1, 131.7 (2C), 130.1 (2C), 121.0, $118.4,108.5,21.3$. MS (relative intensity) $m / z: 434$ (29), 304 (54), 235 (24), 219 (16), 91 (100), 65 (67). HRMS calculated for $\mathrm{C}_{15} \mathrm{H}_{10} \mathrm{~F}_{6} \mathrm{Te}: 433.9748$. Found: 433.9748.

4-Formylphenyl-p-tolyl-telluride (3j)

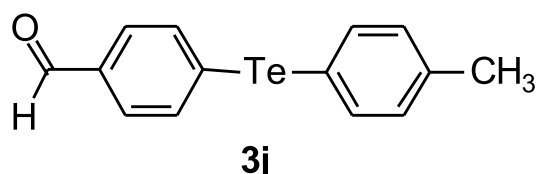

Yield: $72 \% .{ }^{1} \mathrm{H} \mathrm{NMR}\left(\mathrm{CDCl}_{3}, 300 \mathrm{MHz}\right): \delta 9.88(\mathrm{~s}$, $1 \mathrm{H}), 7.73(\mathrm{~d}, J 7.5 \mathrm{~Hz}, 2 \mathrm{H}), 7.51-7.60(\mathrm{~m}, 4 \mathrm{H}), 7.12$ (d, $J$ $7.5 \mathrm{~Hz}, 2 \mathrm{H}), 2.37$ (s, 3H). ${ }^{13} \mathrm{C} \mathrm{NMR}\left(\mathrm{CDCl}_{3}, 75 \mathrm{MHz}\right): \delta$ 191.7, 140.4 (2C), 139.4, 138.0, 135.1 (2C), 130.9 (2C), 130.6, 129.9 (2C), 127.5, 21.4. MS (relative intensity) m/z: 326 (37), 219 (11), 195 (100), 167 (21), 91 (59), 65 (29). HRMS calculated for $\mathrm{C}_{14} \mathrm{H}_{12}$ OTe: 325.9950 . Found: 325.9968 . 
2-Thiophenyl-p-tolyl-telluride (3k)<smiles>Cc1ccc([Te]c2cccs2)cc1</smiles>

Yield: $81 \%$. ${ }^{~} \mathrm{H}$ NMR $\left(\mathrm{CDCl}_{3}, 300 \mathrm{MHz}\right): \delta 7.50$ (d, $J$ $8.1 \mathrm{~Hz}, 2 \mathrm{H}), 7.44-7.47(\mathrm{~m}, 2 \mathrm{H}), 7.01(\mathrm{~d}, J 8.1 \mathrm{~Hz}, 2 \mathrm{H}), 6.96$ $(\mathrm{dd}, J 5.2,3.6 \mathrm{~Hz}, 1 \mathrm{H}), 2.29$ (s, 3H). ${ }^{13} \mathrm{C}$ NMR $\left(\mathrm{CDCl}_{3}, 75\right.$ MHz): $\delta 141.3,137.8,136.2$ (2C), 134.6, 130.1 (2C), 128.8, $111.9,100.6,20.9$. MS (relative intensity) $m / z: 304$ (30), 174 (100), 141 (11), 91 (25), 65 (27). HRMS calculated for $\mathrm{C}_{11} \mathrm{H}_{10} \mathrm{STe}$ : 303.9565 . Found: 303.9579 .

\section{3-Thiophenyl-p-tolyl-telluride (3l)}<smiles>Cc1ccc([Te]c2ccsc2)cc1</smiles>

3I

Yield: $83 \%$. ${ }^{1} \mathrm{H} \mathrm{NMR}\left(\mathrm{CDCl}_{3}, 300 \mathrm{MHz}\right): \delta$ 7.47-7.49 (m, 2H), 7.19-7.22 (m, 2H), 7.17 (s, 1H), 6.96 (d, J 7.8 $\mathrm{Hz}, 2 \mathrm{H}) .{ }^{13} \mathrm{C} \mathrm{NMR}\left(\mathrm{CDCl}_{3}, 75 \mathrm{MHz}\right): \delta 137.9,137.4$, 137.0 (2C), 136.2, 133.4, 130.2 (2C), 126.8, 110.6, 104.1, 21.0. MS (relative intensity) $\mathrm{m} / \mathrm{z}: 304$ (30), 174 (100), 141 (17), 91 (40), 65 (29). HRMS calculated for $\mathrm{C}_{11} \mathrm{H}_{10} \mathrm{STe}$ : 303.9565. Found: 303.9582 .

3-Pyridinyl-telluride (3m)

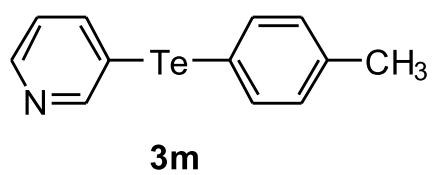

Yield: 78\%. ${ }^{1} \mathrm{H}$ NMR $\left(\mathrm{CDCl}_{3}, 300 \mathrm{MHz}\right): \delta 8.78(\mathrm{~s}$, $1 \mathrm{H}), 8.43(\mathrm{~d}, J 6.5 \mathrm{~Hz}, 1 \mathrm{H}), 7.87(\mathrm{~d}, J 6.5 \mathrm{~Hz}, 1 \mathrm{H}), 7.61(\mathrm{~d}$, $J 7.8 \mathrm{~Hz}, 2 \mathrm{H}), 7.01-7.12(\mathrm{~m}, 1 \mathrm{H}), 6.99(\mathrm{~d}, J 7.8 \mathrm{~Hz}, 2 \mathrm{H})$, $2.32(\mathrm{~s}, 3 \mathrm{H}) .{ }^{13} \mathrm{C} \mathrm{NMR}\left(\mathrm{CDCl}_{3}, 75 \mathrm{MHz}\right): \delta 156.4,148.3$, 144.3, 139.1 (2C), 138.0, 130.7 (2C), 124.6, 113.0, 109.0, 21.2. MS (relative intensity) m/z: 299 (35), 169 (100), 91 (58), 65 (33), 51 (21). HRMS calculated for $\mathrm{C}_{12} \mathrm{H}_{11}$ NTe: 298.9953, Found: 298.9971.
Bis-(4-Methoxyphenyl)-telluride (3n)<smiles>COc1ccc([Te]c2ccc(OC)cc2)cc1</smiles>

Yield: $89 \%$. ${ }^{1} \mathrm{H}$ NMR $\left(\mathrm{CDCl}_{3}, 300 \mathrm{MHz}\right): \delta 7.64$ (d, $J$ $6.2 \mathrm{~Hz}, 4 \mathrm{H}), 6.77(\mathrm{~d}, J 6.2 \mathrm{~Hz}, 4 \mathrm{H}), 3.76(\mathrm{~s}, 6 \mathrm{H}) \cdot{ }^{13} \mathrm{C} \mathrm{NMR}$ $\left(\mathrm{CDCl}_{3}, 75 \mathrm{MHz}\right): \delta 159.7$ (2C), 139.7 (4C), 115.4 (4C), 104.3 (2C), 55.2 (2C). MS (relative intensity) $\mathrm{m} / \mathrm{z}: 344$ (24), 214 (93), 199 (100), 171 (21), 107 (19), 63 (24). HRMS calculated for $\mathrm{C}_{14} \mathrm{H}_{14} \mathrm{O}_{2}$ Te: 344.0056, Found: 344.0067 .

4-Methoxyphenyl-o-tolyl-telluride (3o)

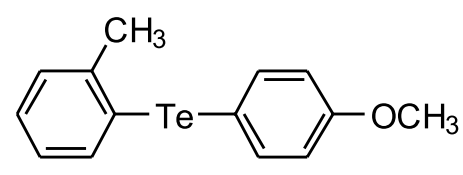

30

Yield: $91 \% .{ }^{1} \mathrm{H} \mathrm{NMR}\left(\mathrm{CDCl}_{3}, 300 \mathrm{MHz}\right): \delta 7.68(\mathrm{~d}, J$ $8.5 \mathrm{~Hz}, 2 \mathrm{H}), 7.23(\mathrm{~d}, J 7.5 \mathrm{~Hz}, 1 \mathrm{H}), 7.05-7.14(\mathrm{~m}, 2 \mathrm{H}), 6.88$ (t, $J 7.5 \mathrm{~Hz}, 1 \mathrm{H}), 6.76(\mathrm{~d}, J 8.5 \mathrm{~Hz}, 2 \mathrm{H}), 3.76(\mathrm{~s}, 3 \mathrm{H}), 2.34$ (s, 3H). ${ }^{13} \mathrm{C} \mathrm{NMR}\left(\mathrm{CDCl}_{3}, 75 \mathrm{MHz}\right): \delta 160.2,141.9$ (2C), 140.8, 135.3, 129.4, 127.4, 126.7, 120.3, 115.7 (2C), 102.5, 55.2, 25.4. MS (relative intensity) $\mathrm{m} / \mathrm{z}: 328$ (61), 220 (25), 198 (100), 183 (51), 91 (74), 65 (47). HRMS calculated for $\mathrm{C}_{14} \mathrm{H}_{14} \mathrm{OTe}$ : 328.0106, Found: 328.0123 .

4-Methoxyphenyl-phenyl-telluride (3p)

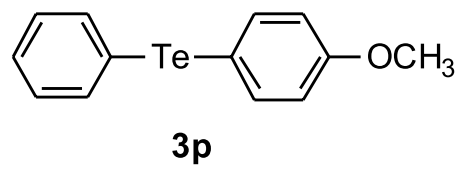

Yield: 94\%. ${ }^{1} \mathrm{H}$ NMR $\left(\mathrm{CDCl}_{3}, 300 \mathrm{MHz}\right): \delta 7.71(\mathrm{~d}$, $J 8.7 \mathrm{~Hz}, 2 \mathrm{H}), 7.54(\mathrm{dd}, J 7.8,1.5 \mathrm{~Hz}, 2 \mathrm{H}), 7.11-7.23$ (m, 3H), $6.77(\mathrm{~d}, J 8.7 \mathrm{~Hz}, 2 \mathrm{H}), 3.76(\mathrm{~s}, 3 \mathrm{H}) .{ }^{13} \mathrm{C} \mathrm{NMR}$ $\left(\mathrm{CDCl}_{3}, 75 \mathrm{MHz}\right): \delta 160.0,141.2$ (2C), 136.4 (2C), 129.4 (2C), 127.3, 116.0, 115.5 (2C), 103.3, 55.2. MS (relative intensity) $\mathrm{m} / \mathrm{z}: 314$ (27), 184 (100), 169 (60), 141 (38), 115 (17), 77 (29). HRMS calculated for $\mathrm{C}_{13} \mathrm{H}_{12}$ OTe: 313.9950 , Found: 313.9968. 
4-Methoxyphenyl-4-chlorophenyl-telluride (3q)

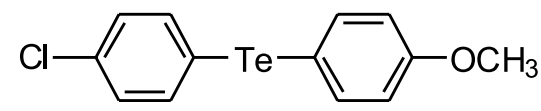

$3 q$

Yield: $91 \% .{ }^{1} \mathrm{H}$ NMR $\left(\mathrm{CDCl}_{3}, 300 \mathrm{MHz}\right): \delta 7.70(\mathrm{~d}, J$ $8.7 \mathrm{~Hz}, 2 \mathrm{H}), 7.44(\mathrm{~d}, J 8.1 \mathrm{~Hz}, 2 \mathrm{H}), 7.11(\mathrm{~d}, J 8.1 \mathrm{~Hz}, 2 \mathrm{H})$, $6.78(\mathrm{~d}, J 8.7 \mathrm{~Hz}, 2 \mathrm{H}), 3.78(\mathrm{~s}, 3 \mathrm{H}) .{ }^{13} \mathrm{C}$ NMR $\left(\mathrm{CDCl}_{3}, 75\right.$ $\mathrm{MHz}): \delta 160.3,141.5$ (2C), 137.8 (2C), 133.8, 129.8 (2C), 115.7 (2C), 113.8, 103.2, 55.3. MS (relative intensity) $\mathrm{m} / \mathrm{z}$ : 348 (29), 218 (100), 203 (51), 175 (24), 63 (19). HRMS calculated for $\mathrm{C}_{13} \mathrm{H}_{11}$ ClOTe: 347.9570, Found: 347.9587.

4-Methoxyphenyl-mesityl-telluride (3r)<smiles>COc1ccc([Te]c2c(C)cc(C)cc2C)cc1</smiles>

Yield: $79 \%$. ${ }^{1} \mathrm{H}$ NMR $\left(\mathrm{CDCl}_{3}, 300 \mathrm{MHz}\right): \delta 7.33$ (d, $J 8.4 \mathrm{~Hz}, 2 \mathrm{H}), 6.95(\mathrm{~s}, 2 \mathrm{H}), 6.68(\mathrm{~d}, J 8.4 \mathrm{~Hz}, 2 \mathrm{H}), 3.75$ (s, 3H), $2.52(\mathrm{~s}, 6 \mathrm{H}), 2.27$ (s, 3H). ${ }^{13} \mathrm{C} \mathrm{NMR}\left(\mathrm{CDCl}_{3}, 75\right.$ $\mathrm{MHz}): \delta 159.1,145.2$ (2C), 139.1, 137.3 (2C), 127.5 (2C), 118.8, 115.4 (2C), 104.7, 55.1, 29.4 (2C), 21.0. MS (relative intensity) $\mathrm{m} / \mathrm{z}: 356$ (100), 248 (65), 226 (74), 211 (61), 119 (97), 91 (76), 77 (61), 65 (27). HRMS calculated for $\mathrm{C}_{16} \mathrm{H}_{18} \mathrm{OTe}$ : 356.0419, Found: 356.0435 .

4-Methoxyphenyl-(1-naphthalenyl)-telluride (3s)

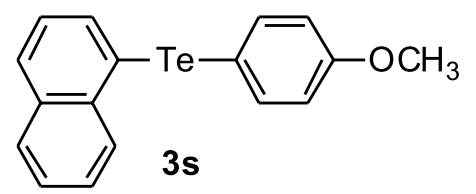

Yield: $87 \% .{ }^{1} \mathrm{H}$ NMR $\left(\mathrm{CDCl}_{3}, 300 \mathrm{MHz}\right): \delta 8.04(\mathrm{~d}$, $J 7.5 \mathrm{~Hz}, 1 \mathrm{H}), 7.73-7.78(\mathrm{~m}, 3 \mathrm{H}), 7.68(\mathrm{~d}, J 8.1 \mathrm{~Hz}, 2 \mathrm{H})$, 7.46-7.52 (m, 2H), 7.19-7.24 (m, 1H), $6.75(\mathrm{~d}, J 8.1 \mathrm{~Hz}$, $2 \mathrm{H}), 3.76$ (s, 3H). ${ }^{13} \mathrm{C} \mathrm{NMR}\left(\mathrm{CDCl}_{3}, 75 \mathrm{MHz}\right): \delta 160.0$, 140.9 (2C), 136.4, 135.5, 133.7, 130.8, 128.7, 128.6, 126.7, 126.5, 126.2, 118.8, 115.6 (2C), 103.0, 55.1. MS (relative intensity) $\mathrm{m} / \mathrm{z}: 364$ (21), 234 (100), 219 (40), 127 (33), 77 (14). HRMS calculated for $\mathrm{C}_{17} \mathrm{H}_{14}$ OTe: 364.0106 , Found: 364.0135 .
2-Thiophenyl-4-methoxyphenyl-telluride (3t)<smiles>COc1ccc([Te]c2cccs2)cc1</smiles>

Yield: 79\%. ${ }^{1} \mathrm{H}$ NMR $\left(\mathrm{CDCl}_{3}, 300 \mathrm{MHz}\right): \delta 7.57$ (d, $J$ $7.8 \mathrm{~Hz}, 2 \mathrm{H}), 7.36-7.39(\mathrm{~m}, 2 \mathrm{H}), 6.88(\mathrm{dd}, J 5.1,3.3 \mathrm{~Hz}, 1 \mathrm{H})$, $6.69(\mathrm{~d}, J 7.8 \mathrm{~Hz}, 2 \mathrm{H}), 3.69$ (s, 3H). ${ }^{13} \mathrm{C} \mathrm{NMR}\left(\mathrm{CDCl}_{3}, 75\right.$ MHz): $\delta 159.8,140.9,139.0$ (2C), 134.5, 129.0, 115.4 (2C), 105.2, 101.6, 55.2. MS (relative intensity) $\mathrm{m} / z: 320$ (27), 190 (100), 175 (89), 147 (31), 63 (18). HRMS calculated for $\mathrm{C}_{11} \mathrm{H}_{10}$ OSTe: 319.9514 , Found: 319.9535 .

(E)-Ethyl 3-p-tolylacrylate (4a)<smiles>CCOC(=O)/C=C/c1ccc(C)cc1</smiles>

Yield: $47 \% .{ }^{1} \mathrm{H}$ NMR $\left(\mathrm{CDCl}_{3}, 300 \mathrm{MHz}\right): \delta 7.65(\mathrm{~d}$, $J 16.0 \mathrm{~Hz}, 1 \mathrm{H}), 7.39(\mathrm{~d}, J 8.1 \mathrm{~Hz}, 2 \mathrm{H}), 7.28(\mathrm{~d}, J 8.1 \mathrm{~Hz}$, 2H), $6.42(\mathrm{~d}, J 16.0 \mathrm{~Hz}, 1 \mathrm{H}), 4.25(\mathrm{q}, J 7.3 \mathrm{~Hz}, 2 \mathrm{H}), 2.33$ (s, 3H), 1.26 (t, J 7.3 Hz). ${ }^{13} \mathrm{C} \mathrm{NMR}\left(\mathrm{CDCl}_{3}, 75 \mathrm{MHz}\right): \delta$ 167.0, 144.5, 134.4, 130.2, 128.8 (2C), 128.0 (2C), 118.3, 60.5, 24.3, 14.5. MS (relative intensity) $m / z: 190$ (24), 117 (45), 91 (23).

(E)-Ethyl 3-(4-methoxyphenyl)acrylate (4b)<smiles>CCOC(=O)/C=C/c1ccc(OC)cc1</smiles>

Yield: $47 \% .{ }^{1} \mathrm{H}$ NMR $\left(\mathrm{CDCl}_{3}, 300 \mathrm{MHz}\right): \delta 7.60(\mathrm{~d}$, $J 16.2 \mathrm{~Hz}, 1 \mathrm{H}), 7.37(\mathrm{~d}, J 8.3 \mathrm{~Hz}, 2 \mathrm{H}), 7.25(\mathrm{~d}, J 8.3 \mathrm{~Hz}$, 2H), $6.40(\mathrm{~d}, J 16.2 \mathrm{~Hz}, 1 \mathrm{H}), 4.23(\mathrm{q}, J 7.3 \mathrm{~Hz}, 2 \mathrm{H}), 3.67$ (s, 3H), 1.25 (t, J 7.3 Hz). ${ }^{13} \mathrm{C} \mathrm{NMR}\left(\mathrm{CDCl}_{3}, 75 \mathrm{MHz}\right): \delta$ 167.2, 144.2, 134.0, 130.1, 128.6 (2C), 128.2 (2C), 118.2, 60.1, 55.7, 14.9. MS (relative intensity) $m / z: 206$ (23), 107 (43), 99 (36). 